\title{
Benefit of the Drinking Water Supply System in Office Building by Rainwater Harvesting: A Demo Project in Hanoi, Vietnam
}

\author{
Anh-Dzung Dao ${ }^{1 \dagger}$,Viet-Anh Nguyen ${ }^{2}$, Mooyoung Han $^{1}$ \\ ${ }^{1}$ Department of Civil and Environmental Engineering, Seoul National University, Seoul 151-742, Korea \\ ${ }^{2}$ Institute of Environmental Science and Engineering, Hanoi University of Civil Engineering, Hanoi 10000, Vietnam
}

\begin{abstract}
Vietnam is a developing country with the rate around 5\%-6\% per year, especially in urban areas. Rapidly developed urban areas lead to stress for infrastructure and the water supply is also stressed. In Hanoi city, total water capacity from the manufactories is around one million cubic meters per day and almost the entire main water source is groundwater but it is not enough to supply all of Hanoi's people, especially in the summer. A demo project is implemented in Hanoi University of Civil Engineering (HUCE) to produce drinking water by using the rainwater and membrane system and supply for people. In this project, rainwater is collected on the rooftop of the lecture building with an area of around $500 \mathrm{~m}^{2}$ and $100 \mathrm{~m}^{3}$ volumetric rainwater tanks. Afterwards, the rainwater is treated by the micromembrane system and supplied to the tap water. Total cost for construction, technology and operation in the first year is around USD 48,558. In the long-term (15 yr) if HUCE invests in the same system, with $20 \mathrm{~m}^{3}$ volumetric storage tank, it can provide drinking water for 500 staffs in every year. The cost of investment and operation for this system is lower than $30 \%$ compared to buying bottled water with the price USD 1.8/bottle. The drinking water parameters after treatment are $\mathrm{pH}, 7.3-7.75$; turbidity, 0.6-0.8 NUT; total dissolved solids, 60-89 mg/L; coliform, 0; heavy metal similar with water quality in the bottle water in Vietnam.
\end{abstract}

Keywords: Drinking water, Rainwater harvesting, Rainwater tank, Water supply

\section{Introduction}

Currently, Hanoi is the biggest city in Vietnam with the development rate of around $6 \%-7 \%$ per year. A lot of the buildings and new urban areas are built in Hanoi city leading the population of Hanoi city to also increase. The rapid development increases stress to the infrastructures, which can be the city's water supply system. The water supply system has been renovated and upgraded in recent years; however the loss of a water system is still high, accounting for $50 \%$ and it can cover the water consumption for 9 inner districts of Hanoi city like Hoan Kiem, Dong Da, Hadong district, etc. The proportion of people who are provided with clean water in these districts range from $90 \%-94.8 \%$ and in the summer this proportion decreases and some places in Hanoi city does not have enough water for daily living. Total capacity of the water manufactory is around 1,000,000-1,200,000 $\mathrm{m}^{3} /$ day and $70 \%$ of the water source is groundwater. In the suburban area of Hanoi city, only $15 \%$ of the population is provided with clean water from Hanoi's water distribution network and the small water treatment plant in the community and town. Other people use the individual tube well to exploit groundwater and they also use the rainwater or surface water for daily living.

Groundwater is exploited with a large capacity in the inner areas of Hanoi city leading to the subsidence of a ground foundation because groundwater was not supplement enough to empty space under the ground. In suburban areas, the groundwater is being polluted because households do not have the skill to operate the tube well and the sanitation system in the villages or communes is very low. With the current status of water utilization, Hanoi should find measures to reduce the negative impact of the development process to ensure both clean water for people and the sustainable exploitation of water sources of the city.

Besides the tap water, at the agencies, commercials area and schools bottled water is the main water source for drinking. The bottled water companies also exploit groundwater and use the reverse osmosis (RO) technology to clean groundwater, bottle it, and provide the bottled water to the market. During the groundwater exploitation, the bottled water companies, government and households do not focus on the groundwater depletion in the city and they also do not think about the solution using a variety of water sources like: using rainwater as drinking water or reusing wastewater for gardens, production processes, etc. (c) This is an Open Access article distributed under the terms of the Creative Commons Attribution Non-Commercial License (http://creativecommons. org/licenses/by-nc/3.0/) which permits unrestricted non-commercial use, distribution, and reproduction in any medium, provided the original work is properly cited.
Received November 02, 2012 Accepted May 21, 2013

${ }^{\dagger}$ Corresponding Author

E-mail: dzung41mtn2@gmail.com

Tel: +82-2880-7375 Fax: +82-2885-7376 

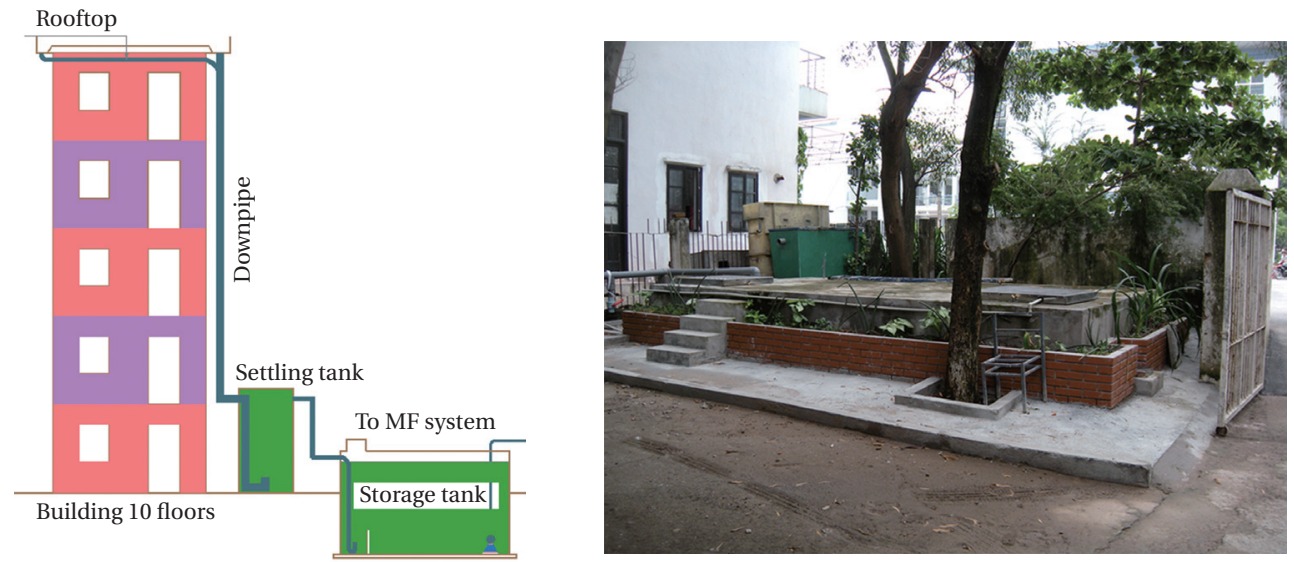

Fig. 1. Rainwater collecting system. MF: micro-filter.

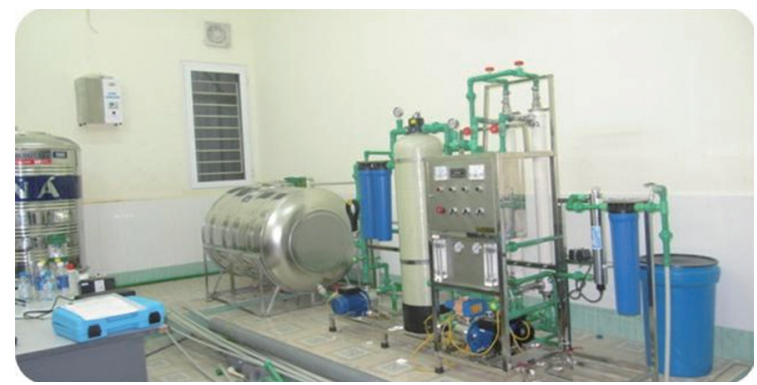

Fig. 2. Membrane filter system.

As for rainwater, many people and the city government said that rainwater in Hanoi city is polluted by the process of urban development and traffic. Typically, rainwater is collected from the catchment or rooftop and drains directly to the sewer system of the city and flows into the river but this measure causes some problems like flooding on the street in Hanoi city, especially during the rainy season. A lot of solutions were implemented but flooded situation is still increase. Through the experience of Star City, high buildings in Seoul, Korea, Institute of Environmental Science and Engineering (IESE), Hanoi University of Civil Engineering (HUCE) cooperated with Rainwater Research Center, Seoul National University implemented a project about rainwater harvesting in urban areas, using membrane technology to treated rainwater and supply for drinking. Initially, the project has achieved some positive results with water quality output ensures drinking water standards and then introduce the benefit of this system to the market.

\section{Materials and Methods}

\subsection{Rainwater Collecting System}

A rainwater collecting system was built in the precinct of the IESE, HUCE. It was started from December 2010 and completed in May 2011. This system includes the storage tank, catchment, piping system, and a settling tank (Fig. 1). The rooftop of the laboratory building is used like a catchment for this system with an

area of $500 \mathrm{~m}^{2}$ and the height is around $30 \mathrm{~m}$. The storage tank was built with $50 \mathrm{~m}^{3}$ volumetric and concrete material, and the inside of the tank is covered by a white tile to reduce the potential growth of the algae. The dimensions of the tank are $5.5 \mathrm{~m} \times 3.5 \mathrm{~m}$ $\times 2.6 \mathrm{~m}$ with half under the ground and the other on the ground and we also use the steel tank to store rainwater. Total volume of the concrete and steel tank is $100 \mathrm{~m}^{3}$. The settling tank is installed before the storage tank like the primary sedimentation unit. Volume of this tank is around $1.2-1.5 \mathrm{~m}^{3}$ with the cylindrical shape and it is made by composite material. The piping system consisted of the PVC pipe has a diameter of $110 \mathrm{~mm}$ and is connected to the catchment, settling tank and storage tank. Inside of the storage tank, the calm inlet is also designed to avoid mixing sludge on the bottom. This collecting system has been operating from June, 2011 until now.

\subsection{Membrane System}

To supply pure water for the staff of the IESE, rainwater is treated by the membrane system. Rainwater is pumped from the external storage tank to the raw water tank of the membrane system and then it is cleaned continuously though the micro-filter (MF) module before being supplied to the user. The components of the membrane system are the MF module, fiber filter, active carbon filter, ozone machine, and UV light (Fig. 2). Specifications of the MF module (H2L, Anyang, Korea) are as follows: pressure,

Table 1. Operation parameters of the micro-filter (MF) system

\begin{tabular}{lcc}
\hline Parameter & H2L & China \\
\hline Qvh (L/min) & 10 & \\
Feeding pump & & $5-45$ \\
Q (L/min) & $5-70$ & $28-11.5$ \\
H (m) & $21-43$ & 32 \\
Hmax (m) & 28 & \\
Pressure (MPa) & & \\
After pump 1 & 0.1 & \\
Before FF & 0.02 & \\
Before MF & 0.02 & \\
After MF & 0.01 &
\end{tabular}

FF: fiber filter. 
0.01-0.02 MPa; feeding pump, 21-43 m; dimension of the MF, length, $1.2 \mathrm{~m}$; diameter, $0.06 \mathrm{~m}$. Other items were imported from China and the specifications and the operating parameter of the system are shown in Table 1 . The system is operated in semi-automatic mode with the operating time being from $8 \mathrm{AM}$ to $6 \mathrm{PM}$ during working days.

\subsection{Market Survey and Investigation}

Currently, 400 brands are in the bottled water market at Hanoi city. Some of the big companies like Aquafina, Lavie, Laiska, etc. invest lots of money to produce bottled water processed through high technology. Besides, a lot of bottled water brands are produced by small companies or family companies. Most of these companies extract groundwater and treat it with RO technology before selling to the market. In the large companies, the production processes are strictly controlled through the regulations of quality and product safety, but many of the small companies do not fully implement the regulation about hygiene products during the production process leading in some cases the water quality is not ensure hygienic and inside of the water bottled has the sludge or algae on the bottom of the water bottled. The prices of the bottled water change depending on the brands, varying from VND 5,000-7,000 (Vietnamese Dong, equal to USD 0.19-0.33) for $0.5 \mathrm{~L}$ of bottled water; VND 35,000-65,000 (USD 1.8-3.8) for $20 \mathrm{~L}$ of bottled water (Table 2).

As for tap water, groundwater is the main water source to provide for domestic consumption to Hanoi citizens. Capacity of the groundwater that are being exploited by 12 manufactories in Hanoi city amount to approximately $750,000 \mathrm{~m}^{3} /$ day. Water qualities at the outlet of most factories are guaranteed to meet drinking water standards, however, in some water treatment plants, especially at the south of Hanoi city like Tuongmai, Hadinh, Phapvan (capacity, 120,000 $\mathrm{m}^{3} /$ day) the groundwater is polluted by ammonia $\left(\mathrm{NH}_{4}^{+}\right)$with the content around $7-30 \mathrm{mg} / \mathrm{L}$ (standard, $3 \mathrm{mg} / \mathrm{L}$ ). Therefore, some Hanoi citizens are still facing the possibility of polluted groundwater negatively affecting their health. The price of tap water changes depending on the volume and utilization purpose shown in Table 2.

Table 2. Price (USD) of the tap and bottled water

\begin{tabular}{cc}
\hline & Price (USD) \\
\hline Tap water $($ consumer) & \\
Household $\left(\mathrm{m}^{3}\right)$ & 0.15 \\
4 & 0.23 \\
$4-6$ & 0.33 \\
$>6$ & 0.15 \\
Office & 0.28 \\
Manufactory & 0.375 \\
Business \& services & \\
Bottled water (brand, 20 L/bottle) & 3.8 \\
Aquafina & 2.4 \\
Lavie & 2.2 \\
Vital & 2 \\
Tienhai & 1.9 \\
Laska & 2.4 \\
VinhHao & 1.8 \\
Victory & 2 \\
Hoabinh &
\end{tabular}
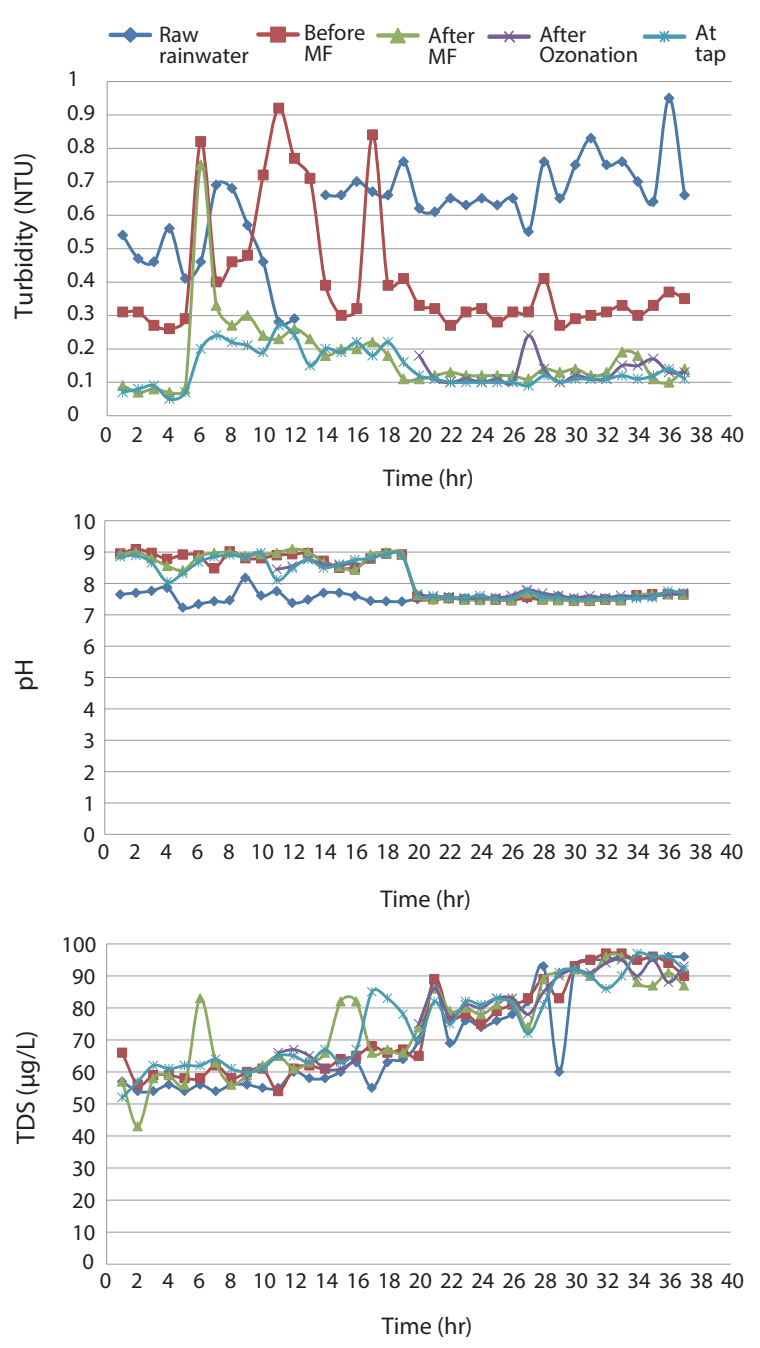

Fig. 3. Water quality (turbidity, pH, total dissolved solids [TDS]) through membrane filter system. MF: micro-filter.

\section{Results and Discussion}

\subsection{Technical Aspect}

\subsubsection{Rainwater quantity}

$120 \mathrm{~m}^{3}$ of rainwater collected from June until August 2011 was used to clean the rainwater tank. From October 2011 rainwater was stored and used to test the operation of the membrane system. The rainfall average of Hanoi was about $50 \mathrm{~mm} / \mathrm{hr}$ from October until December 2011. Total rainwater collected during this period was around $350 \mathrm{~m}^{3}$. Storage of rainwater in the tank also reduced the peak flow to the sewer system and it turned out that rainwater storage could be a measure to reduce the local flooding situation on the streets of Hanoi city [1].

\subsubsection{Rainwater quality}

Rainwater treatment system was installed following the membrane technology and it was completed in December 2011; it was operated to test system before supply to the staff in the IESE. This system is operated to follow the main regime includ- 
ing the following steps: Rainwater tank $\rightarrow$ Raw water tank $\rightarrow$ Fiber filter $\rightarrow$ MF membrane $\rightarrow$ Ozonation $\rightarrow$ Tap water. The parameters to estimate water quality in this case are turbidity, $\mathrm{pH}$, total dissolved solids (TDS), chemical oxygen demand (COD), total nitrogen (TN), coliform, and E. coli, and the samples were taken at 5 points in the membrane system: raw water tank, before and after MF membrane, before the ozonation, and at the tap. The result of the testing period (Fig. 3) demonstrated that the MF membrane system is operated well and water quality parameters are guaranteed with the Vietnam drinking water standard. Rainwater in the raw water tank has the basic parameters like turbidity, 0.6-0.8 NTU; pH, 7.3-7.75; TDS, 60-98 mg/L. These parameters are close with the standard because rainwater was stored in the concrete tank within around 1 month so sediments settled on the bottom of the tank and $\mathrm{pH}$ concentration also became neutralization. At other sampling position, parameters are also guaranteed with the standard as: turbidity $<0.4$ NTU; $\mathrm{pH}, 7.4-7.7$; TDS, 60-98 $\mathrm{mg} / \mathrm{L}$, and the biochemical parameter as COD, TN, coliform, and E. coli are checked at the tap and the result showed that it coincides with the Vietnam drinking water standard (Fig. 3). Thus, during the testing operation process rainwater is treated to guarantee quality in regard to Vietnam's drinking water standard.

\subsection{Economic Aspect}

3.2.1. Drinking water consumption and rainwater tank volume

HUCE has 500 staffs working per day and they usually use bottle water with $20 \mathrm{~L}$ volumetric. Total drinking water con-

Table 3. Drinking water consumption at Hanoi University of Civil Engineering

\begin{tabular}{lr} 
Staff (person) & 500 \\
Water capacity (L/bottle) & 20 \\
Bottle per day & 25 \\
Working day per month & 24 \\
Water consumption $\left(\mathrm{m}^{3}\right)$ & \\
Per month & 12 \\
Per year & 132 \\
\hline
\end{tabular}

Table 4. Water quality (metal) though micro-filter (MF) system

\begin{tabular}{lcccc}
\hline Parameter & $\begin{array}{c}\text { Raw } \\
\text { rainwater }\end{array}$ & $\begin{array}{c}\text { Before } \\
\text { MF }\end{array}$ & $\begin{array}{c}\text { After } \\
\text { MF }\end{array}$ & $\begin{array}{c}\text { At } \\
\text { tap }\end{array}$ \\
\hline Temperature $\left({ }^{\circ} \mathrm{C}\right)$ & 24.0 & 24.1 & 24.2 & 24.0 \\
$\mathrm{COD}(\mathrm{mg} / \mathrm{L})$ & 2.83 & 1.17 & 1.13 & 1.05 \\
$\mathrm{TN}(\mathrm{mg} / \mathrm{L})$ & 0.038 & 0.033 & 0.023 & 0.020 \\
$\mathrm{TP}(\mathrm{mg} / \mathrm{L})$ & 0.49 & 0.70 & 0.49 & 0.35 \\
$\mathrm{Coliform}$ & 21 & 4 & 0 & 0 \\
$($ E.coli/1,000 mL) & & & & \\
$\mathrm{Pb}(\mathrm{mg} / \mathrm{L})$ & 0.0009 & 0.0052 & 0.0003 & $<0.0001$ \\
$\mathrm{As}(\mathrm{mg} / \mathrm{L})$ & 0.0027 & 0.0023 & 0.0024 & 0.0022 \\
$\mathrm{Ni}(\mathrm{mg} / \mathrm{L})$ & 0.002 & 0.004 & 0.003 & 0.002 \\
$\mathrm{Fe}(\mathrm{mg} / \mathrm{L})$ & 0.169 & 0.189 & 0.157 & 0.142 \\
$\mathrm{Mn}(\mathrm{mg} / \mathrm{L})$ & 0.005 & 0.003 & 0.001 & $<0.001$ \\
$\mathrm{Zn}(\mathrm{mg} / \mathrm{L})$ & 0.291 & 0.150 & 0.005 & 0.020 \\
$\mathrm{Cu}(\mathrm{mg} / \mathrm{L})$ & 0.020 & - & - & $<0.001$ \\
\hline
\end{tabular}

COD: chemical oxygen demand, TN: total nitrogen, TP: total phosphorus.
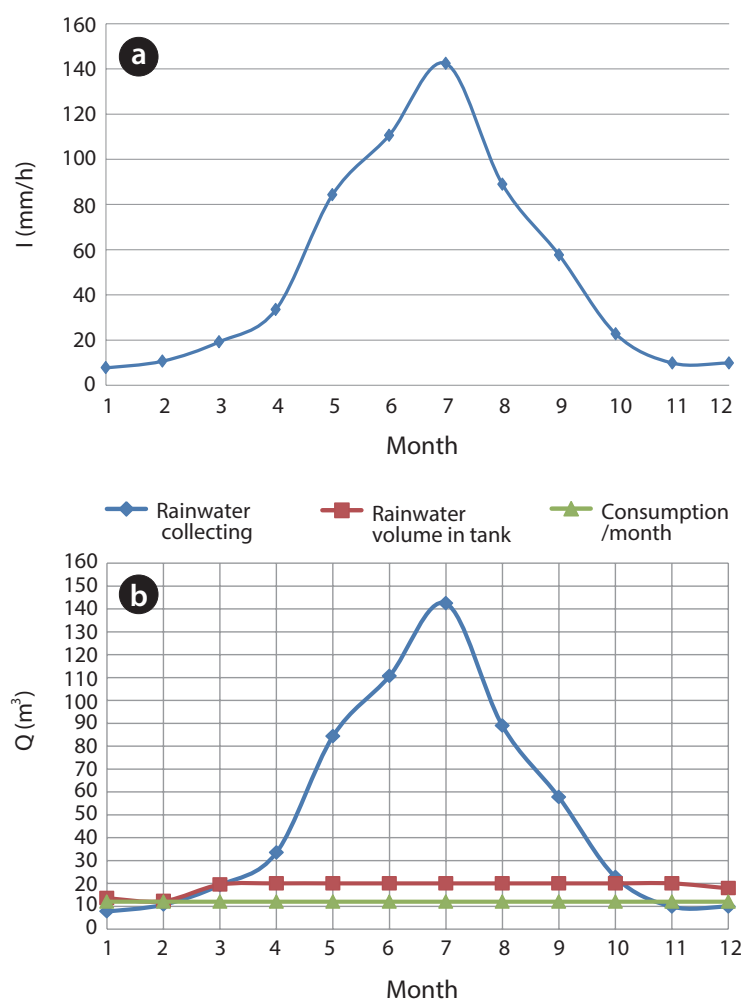

Fig. 4. Drinking water consumption and rainwater volume in storage tank. (a) Average rainfall in Hanoi city (2000-2011) and (b) rainwater volume in tank.

sumption is shown in Table 3. Drinking water consumption for HUCE is $12 \mathrm{~m}^{3} /$ month, therefore a rainwater storage tank should be built that can provide water consumption for all individuals. Based on the rainfall date of Hanoi city within 2000-2011, a tank with $20 \mathrm{~m}^{3}$ volumetric should be built (Fig. 4). In the demo project, the storage tank is $100 \mathrm{~m}^{3}$ but if HUCE invest in a system like the demo project, the tank volume is $20 \mathrm{~m}^{3}$ and the cost to build the system is decreased. Based on the tank construction cost (Table 4) we can calculate the cost to build the $20 \mathrm{~m}^{3}$ tank volumetric for HUCE.

\subsubsection{Demo project cost and investment cost}

The demo project cost includes the construction and operation cost. The items of the construction work are the rainwater tank, rainwater collecting piping system-control house and membrane system, and operation work includes electrical, chemical, and maintenance (Table 5).

Investment cost also includes the construction and operation cost but in the construction cost the rainwater tank is smaller than the one in the demo project leading to a reduction in cost. Operation cost should include the employer salary and the cost to buy the plastic bottles (Table 6).

\subsubsection{Comparison with bottle water}

If HUCE decides to build the rainwater harvesting system to provide drinking water for staffs within 15 years, the investment cost is calculated in the following Eq. (1) [2].

$$
F V=P V \cdot(1+i)^{n}
$$


Table 5. Cost for demo project case

\begin{tabular}{|c|c|c|c|c|}
\hline \multirow{2}{*}{ Item } & \multirow{2}{*}{ Amount } & \multirow{2}{*}{$\begin{array}{l}\text { Unit } \\
\text { price }\end{array}$} & \multicolumn{2}{|c|}{ Cost } \\
\hline & & & $\begin{array}{l}\text { Million } \\
\text { VND }\end{array}$ & USD \\
\hline \multicolumn{5}{|l|}{ Construction } \\
\hline $\begin{array}{l}\text { Storage tank include } \\
\text { pump }\left(\mathrm{m}^{3}\right)\end{array}$ & 100 & - & 723 & - \\
\hline First flush tank $\left(\mathrm{m}^{3}\right)$ & 3 & - & 7 & - \\
\hline Piping system & 1 & - & 5 & - \\
\hline Control house $\left(\mathrm{m}^{2}\right)$ & 15 & - & 95 & - \\
\hline Membrane system & 1 & - & 180 & - \\
\hline Total project cost & - & - & 1,010 & 48,558 \\
\hline \multicolumn{5}{|l|}{ Operation } \\
\hline Electrical (kW) & 50 & 0.052 & - & 2.6 \\
\hline $\begin{array}{l}\text { Chemical } \\
\left(\mathrm{NaOCl}, \mathrm{H}_{2} \mathrm{SO}_{4} \text { set }\right)\end{array}$ & 1 & 4.9 & - & 4.9 \\
\hline Maintenance & 1 & 5.9 & - & 5.9 \\
\hline Sum (cost/month) & - & - & - & 13.4 \\
\hline Cost/year & - & - & - & 161.0 \\
\hline
\end{tabular}

Table 6. Cost for investment case

\begin{tabular}{|c|c|c|c|c|}
\hline \multirow{2}{*}{ Item } & \multirow{2}{*}{ Amount } & \multirow{2}{*}{$\begin{array}{l}\text { Unit } \\
\text { price }\end{array}$} & \multicolumn{2}{|c|}{ Cost } \\
\hline & & & $\begin{array}{l}\text { Million } \\
\text { VND }\end{array}$ & USD \\
\hline \multicolumn{5}{|l|}{ Construction } \\
\hline $\begin{array}{l}\text { Storage tank include } \\
\text { pump }\left(\mathrm{m}^{3}\right)\end{array}$ & 20 & - & 217 & - \\
\hline First flush tank $\left(\mathrm{m}^{3}\right)$ & 3 & - & 7 & - \\
\hline Piping system & 1 & - & 5 & - \\
\hline Control house $\left(\mathrm{m}^{2}\right)$ & 15 & - & 95 & - \\
\hline Membrane system & 1 & - & 180 & - \\
\hline Total investment cost & - & - & 504 & 24,470 \\
\hline \multicolumn{5}{|l|}{ Operation } \\
\hline $\begin{array}{l}\text { Employee salary } \\
\text { (person) }\end{array}$ & 2 & 96 & - & 192 \\
\hline Electrical (kW) & 50 & 0.052 & - & 2.6 \\
\hline $\begin{array}{l}\text { Chemical } \\
\left.\text { (NaOCl, } \mathrm{H}_{2} \mathrm{SO}_{4} \text { set }\right)\end{array}$ & 1 & 4.9 & - & 4.9 \\
\hline Maintenance & 1 & 5.9 & - & 5.9 \\
\hline Sum (cost/month) & - & - & - & 205.4 \\
\hline Cost/year & - & - & - & 2,465 \\
\hline Plastic bottle & 50 & 2.05 & - & 102 \\
\hline Total cost/year & - & - & - & 2,567 \\
\hline
\end{tabular}

Table 7. Cost of the bottled water per year

\begin{tabular}{lr} 
Staff (person) & 500 \\
Drinking water consumption (L/person/day) & 1 \\
Total water (L/month) & 12,000 \\
Cost/month (USD) & \\
Min 1.8 & $1,136.8$ \\
Max 3.8 & 2,400 \\
Cost/year (USD) & \\
Min 1.8 & $12,505.2$ \\
Max 3.8 & 28,800 \\
\hline
\end{tabular}

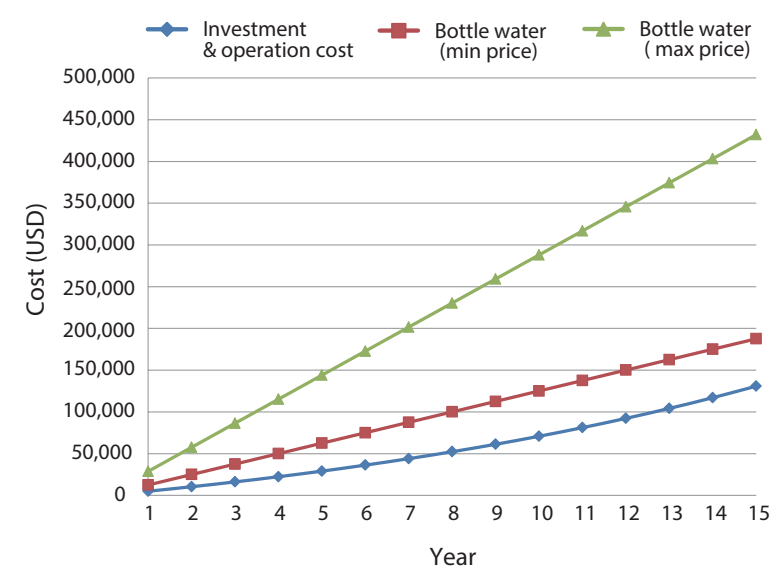

Fig. 5. Comparison cost between rainwater and bottle water.

Where, PV is the present value and it can be calculated in the following Eq. (2) [3].

$$
\mathrm{PV}=\mathrm{A}\left[\frac{(1+i)^{n}-1}{i(1+i)^{n}}\right]
$$

$n$ is the number of compounding periods (not necessarily an integer), $i$ is the interest rate for that period, in this case $i=7.5 \%$ (Vietnam's National Bank), and A is the end-of-period cash receipt [4].

Normally, they would use bottled drinking water, which varies in price between VND 35,000 and 46,000 (USD 1.8-2.2) for a 20 -L bottle. The costs for supplying bottled water are given in Table 7. If we use the maximum price for bottled water of USD 3.8 (brand Aquafina, Lavie), the profit would be around 2-2.5 times that of the investment and operation of the rainwater harvesting system (Fig. 5). Therefore, investment in the rainwater harvesting system using membrane technology would be more cost effective in the long-term ( $15 \mathrm{yr}$ ) than buying bottled water for staff in HUCE.

\subsection{Social Aspect}

In Hanoi city, almost all of the citizens think that they cannot use the rainwater for drinking because the air pollution issue in Hanoi. Rainwater is not collected and stored at the households or department, commercial building, office building.

Although, there are some households still collecting and storing rainwater to use like domestic water and they use it for washing, garden irrigation but until now they did not find a measure to treat rainwater for drinking. So, if a pilot system concerning rainwater harvesting for drinking shows good results it will demonstrate a new approach for people and they can apply it to obtain clean water for drinking and cooking. After the rainwater harvesting system in HUCE operated with good results, a newspaper wrote about this system and it received around 40 comments from readers, $65 \%$ of the comments said that this is a good solution and it should be researched continuously before applying it to the market; $25 \%$ of the comments were about the investment and construction price; $10 \%$ of the comments think that it is difficult to apply this system to the market. In addition, 
the system has been showed on a Vietnam television station, categories: innovation solution gave a solution that can be applied to supplement a clean water source in Hanoi city, especially in the summer. This is an information channel having a direct impact on the community and helps the community change their mind about rainwater harvesting in urban areas. It also demonstrates the approach of the flexible solution to use water sources to reduce the stress to exploit groundwater sources in Hanoi city.

\section{Conclusions}

In this study, rainwater is collected to supply for drinking water with membrane technology. The demo project in HUCE is showed that at urban areas in Vietnam today, collecting and treating rainwater is also an option to provide drinking water for offices, agencies, universities, etc. Rainwater quality guarantees Vietnam's drinking water standard and is close to the bottled water quality. At HUCE, with $20 \mathrm{~m}^{3}$ volumetric of the storage tanks and $500 \mathrm{~m}^{2}$ harvested catchment area, it can provide drinking water for 500 staffs all year. The cost to invest and operate this system in 15 years is lower that $30 \%$ of that regarding buying bottled water. In addition, this system received around $60 \%$ positive comments from newspaper readers and it also changed the opinion of the reader about rainwater utilization in Hanoi city.

\section{References}

1. Mun JS, Yoo HG, Han MY. Particle removal in a rainwater storage tank, and suggestions for operation \& design. J. Korean Soc. Water Wastewater 2007;21:131-138.

2. Stickney CP, Weil RL, Schipper K, Francis J. Financial accounting: an introduction to concepts, methods, and uses. Mason: South-Western Cengage Learning; 2010.

3. Newnan DG, Lavelle JP, Eschenbach T. Essentials of engineering economic analysis. 2nd ed. New York: Oxford University Press; 2002.

4. Rahman A, Keane J, Imteaz MA. Rainwater harvesting in Greater Sydney: water savings, reliability and economic benefits. Resour. Conserv. Recycl. 2012;61:16-21. 